\title{
Size dependency of variables influencing fire occurrence in Mediterranean forests of Eastern Spain
}

\author{
Marina Peris-Llopis ${ }^{1} \mathbb{D}$. José Ramón González-Olabarria ${ }^{2} \cdot$ Blas Mola-Yudego $^{1}$
}

Received: 24 May 2019 / Revised: 24 January 2020 / Accepted: 10 February 2020 / Published online: 28 February 2020

(c) The Author(s) 2020

\begin{abstract}
Fires are among the most damaging disturbances to forests in the Mediterranean area. The study analyses the occurrence and characteristics of forest fires in Eastern Spain (1993-2015) to identify key variables related to burnt forest land, differentiating fires according to their burnt area. Data are retrieved from digital cartography, the Spanish Forest Map and data concerning fires. Based on previous research, the variables included are altitude, slope, aspect, fuel, species, population and road density. The fires are classified in small (5-50 ha), medium (50-500 ha) and large (>500 ha). Four models are considered to explain the proportion of burnt area based on weighted generalized linear models: a general model and one per size class. The results highlight the different relations of similar variables with fires according to the size. When a single model is considered to explain all area burnt, the relationships are mainly driven by large fires. The larger area is burnt on forests with pine, bushes and small trees, whereas smaller fires tend to occur on lower altitude, low slope, high population and road densities. There are large differences in the variables according to the fire sizes, especially for the presence of pine (negative in the medium fires model but positive for the large fires model) and Pasture (which only explains the small fires). The models can be applied to analyse occurrence by fire size in Mediterranean areas, and the results can help elaborate fire prevention strategies and land-planning schemes.
\end{abstract}

Keywords Burnt area $\cdot$ Fire occurrence $\cdot$ Fire size $\cdot$ Weighted generalized linear model

\section{Introduction}

Fires are among the most destructive disturbances in forests, affecting not only their functions but also altering the forest composition and its ability to recover (e.g. Parente and Pereira 2016), causing economic and ecologic damage and even the loss of human lives. In recent years, it has been forecasted that climate change will result in more frequent and larger areas affected by fires (Fox et al. 2016; Moriondo et al. 2006; Prăvălie 2018; Turco et al. 2018). Perhaps more dramatically, it is anticipated that extreme events will become more frequent, in the form of mega-fires, which

Communicated by Miren del Rio.

Marina Peris-Llopis

marinp@uef.fi

1 School of Forest Sciences, University of Eastern Finland, Yliopistokatu 7, P.O. Box 111, 80101 Joensuu, Finland

2 Joint Research Unit CTFC - AGROTECNIO, Ctra de St. Llorenç de Morunys, Km 2, 25280 Solsona, Spain overcome suppression efforts and threaten public safety (Williams 2013).

This is particularly relevant in Mediterranean forests, where fires have historically shaped landscapes. The annual average burnt area in the area is estimated around 430,000 ha, with approximately 57,000 fires annually (Ager et al. 2014; European Commission 2011). In the case of Spain, despite fire suppression and prevention measures taken during the four last decades, the number of forest fires has increased from 1900 fires at the beginning of 1970 to more than 8000 , most of them caused by human activities (Alexandrian and Esnault 1999; Goldammer 2003). The good news is that part of this increment can be explained by improvements in the reporting methods and, therefore, better quality of the data (Chuvieco and Martin 2004).

Despite the complexity of its study and regarding the predictability of burnt area and occurrence of forest fires, many factors have been proposed in relation to fire regimes, including climate (e.g. Piñol et al. 1998; Jiménez-Ruano et al. 2019), landscape configuration, structure of fuels and human activity (e.g. Badia et al. 2002; Pausas and 
Fernández-Muñoz 2012), among others. In recent years, several studies have aimed to identify the main variables related to forest fires in Mediterranean areas (in terms of their size, intensity, behaviour, etc.), as for example, through the generation of models to assess occurrence patterns (González et al. 2006; González and Pukkala 2007; Marques et al. 2011a), damage (Botequim et al. 2017; González et al. 2007; Marques et al. 2011b) and the overall characterization of fire regimes (Mateus and Fernandes 2014; San-Miguel-Ayanz et al. 2013).

However, there are important differences in the role of these factors in relation to the size of the fires: large fires present topographic, socio-economic, forest-related variables and ignition's causes that differ from small fires. Arguably, these differences and the weather conditions determine the final burnt area (Cui and Perera 2008). This implies that the prevention strategies must differ based on the fire size, considering the differences on fire occurrence patterns, identifying the factors that can be linked, and placing special focus on those that can be effectively modified through prevention policies. Previous studies identified prevention management actions depending on the factors that influence forest fires, for instance, focusing on the fuel treatments that can mitigate fire hazard (Agee and Skinner 2005) or on the influence of fuel patterns in fire spread at landscape level and the treatments reducing fire spread rates (Finney 2001; Loehle 2004). In relation to fire behaviour, Gonzalez-Olabarria et al. (2019) studied the allocation of strategic areas to improve fire suppression against large fires, identifying areas that meet certain requirements related to accessibility, water supply and fuel management opportunities, and later defining tactical actions for those areas. Similarly, Alcasena et al. (2016) identified priority areas for mitigation as a result of fire spread modelling and wildfire simulations (considering fuel type, moisture content, etc.). Regarding fire ignition occurrence, the identification of hot spots and their causes can be used to design educational campaigns and law measures in those areas (Gonzalez-Olabarria et al. 2012).

Modelling the differences in the variables according to burnt area and understanding the management alternatives contributing to fire prevention are essential to designing preventive measures. This approach can potentially contribute to improve fire prevention strategies taking into account the spatial component of these disturbances and the final burnt area. In the last 20 years, fires have burnt more than 280,000 ha of forest land in Eastern Spain (Сотиnitat Valenciana), causing important economic losses and degrading vulnerable ecosystems. As in other Mediterranean regions and countries (Ager et al. 2014; European Commission 2011), most of the fires were caused by humans: deliberated or due to accidents and neglection. The present study analyses the spatial dimension of forest fire patterns in the region based on empirical records. The objective is to identify the main variables describing the characteristics of the areas burnt according to the eventual size of the fire event, by using models with descriptors based on topography, land uses, structure of living fuels and socio-economic variables.

\section{Materials and method}

\section{Study area and data sources}

The study entailed the Comunitat Valenciana located in Eastern Spain (Comunitat Valenciana, NUTS ES52), which is formed by three provinces: Alicante/Alacant, Castellón/Castelló and Valencia/València (ES521, ES522 and ES523, respectively), covering $23,255 \mathrm{~km}^{2}$, and with an altitude ranging from sea level up to $1838 \mathrm{~m}$. The forest land, which covers approximately $56 \%$ of the study region $(1,267,042 \mathrm{ha})$, is divided into woodland or tree covered forest (tree coverage from 5 to $20 \%$, including sparse forest), which covers 747,825 ha, and non-tree covered forest (tree coverage lower than 5\%, e.g. bushes and pasture lands), with 519,217 ha. The forest area is dominated by Pinus halepensis, covering $72 \%$ of the tree covered forest land (518,664 ha). Regarding the non-tree covered forest, garrigue (Quercus sp.) is the dominant shrub formation (159,578 ha), followed by Rosmarinus sp. formations (52,799 ha) (Valenciana 2015). The study area is densely populated with nearly to 5 million inhabitants in 2017 and more than 3 million households in 2011 (Instituto Nacional de Estadística 2018). Population is unequally distributed through the territory, with higher densities near the coastline and depopulated rural areas [6.8\% of the population live in rural areas (Valenciana 2011)].

The study region is one of the regions with higher occurrence of large fires in the country (Ministerio de Agricultura, Pesca y Alimentación 2019), where an increasing incidence of high-intensity plume-dominated fires has been reported (Barberà et al. 2015). According to the decennial fire reports from the Spanish Ministry for the Ecological Transition, the studied region was the fourth region in the country with the largest percentage of forest area affected by large fires in relation to the total burnt forest area during the period 1996-2005 (Ministerio de Medio Ambiente 2006), ascending to the third position during the period 2001-2010 (Ministerio de Agricultura, Alimentación y Medio Ambiente 2012) and to the second position in the period 2006-2015 (Ministerio de Agricultura, Pesca y Alimentación 2019).

The characterization of forest fires in the study area was based on data concerning number and type of forest fires, date of the fire events, cause, meteorological conditions, perimeter and occurrence, provided by Centro de Información y Documentación Ambiental de la Comunitat 
Valenciana (CIDAM), Dirección General de Prevención de Incendios Forestales, Conselleria de Agricultura, Medio Ambiente, Cambio Climático y Desarrollo Rural (Valenciana 2018), during the period 1993-2015. The data contained recorded information from 10,722 fire events, affecting a total of $301,483.5$ ha from which 285,024 ha were forest lands.

Additional data were retrieved from the Spanish Forest Map (MFE50), with scale 1:50.000, elaborated by Ministerio de Agricultura, Alimentación y Medio Ambiente (1997-2006), with measurements in the study area during the years 2000-2003. The map collects data about the situation of the forests, taking into account its composition and structure. Parameters like tree coverage, the different species occupation and its stage of development conform the cartography of the MFE50.

Data on slope, aspect and altitude were extracted from the Digital Terrain Models of the region (1:200) provided by Instituto Geográfico Nacional. Concerning data of road network, it was retrieved from Centro Nacional de Información Geográfica and elaborated by the Instituto Geográfico Nacional. Finally, data concerning population density was retrieved from disaggregated Corine land cover 2000 (EEA/JRC) maps following Gallego (2010).

\section{Methods}

Forest lands were classified according to altitude, slope, aspect, fuel, species, population density and road density (Table 1), following a similar approach to González and Pukkala (2007) and Marques et al. (2011a). Fuel and species classes were created using the data from the Spanish Forest Map (MFE50) measurements (data from 2000-2002 for ES521 and ES523, and 2003 for ES522). Fuel classes were defined according to the stage of development of the dominant species and the structural type (vegetation structure by land use). In case that the vegetation cover was less than $20 \%$, the fuel class was 0 . In those cases, it was considered that there was not enough vegetation and fuel to be included in the models. The variable fuel was considered with the values 1-4 depending on the dominance of pasture, bushes or trees at different stages of development (according to Table 1). Similarly, the species class was 0 when the tree coverage was less than $20 \%$. The variable species was obtained after a preliminary analysis of the present tree species in the study area, which indicated that the dominant tree species is Pinus halepensis with the largest coverage in comparison with the other species. In order to also consider other pine species present (e.g. Pinus nigra), P. halepensis was grouped with other pine species under the class pine. The class oak grouped all the present oak species in the study area (e.g. Quercus ilex and Quercus robur). Other species included among others: Juniperus sp., Phoenix sp., Olea europaea, Fagus sylvatica. The population density map was used to create the population density classes and average population densities, which were used as an input for the models (together with the rest of classes in Table 1). The country road network was used to calculate road density, through the line density function from ArcGIS software. The criteria to establish the intervals for each variable depended on the maximum and minimum values present in the study area for each one. Through the analysis of the histograms of the variables and using as a guide the intervals established by González and Pukkala (2007) and Marques et al. (2011a), the limit values of the intervals and classes were determined.

Layers with all the classes per variable were created through the raster package in R (Hijmans 2017) and merged with ArcGIS. This operation generated 6997 strata for the whole region, or land areas with similar attributes for potential management and planning purposes (Bettinger et al. 2016), with particular combinations of all variables classified in Table 1, which contained 578,446 cells (measuring $200 \times 200 \mathrm{~m}$ each cell). In order to improve the models, the average values of altitude, slope, road density and population density for each $200 \times 200 \mathrm{~m}$ cell were utilized through the use of a grid with the average values of those variables overlapped to the strata. In this way, the average values for each cell are used as an input for the models. In the models, aspect, fuel and species were considered as dummy variables, included according to the created classes. Once all

Table 1 Variables used to classify land area in the Comunitat Valenciana (Eastern Spain)

\begin{tabular}{ll}
\hline Variables & Classes \\
\hline Altitude $(N=5)$ & $0-200 \mathrm{~m}, 200-600 \mathrm{~m}, 600-1000 \mathrm{~m}, 1000-1400 \mathrm{~m}, 1400-2100 \mathrm{~m}$ \\
Slope $(N=5)$ & $<3 \%, 3-12 \%, 12-20 \%, 20-35 \%,>35 \%$ \\
Aspect $(N=4)$ & $315-45^{\circ}$ (North), 45-135 (East), 135-225 (South), 225-315 (West) \\
Fuel $(N=5)$ & Vegetation cover $<20 \%$, pasture, bushes and small trees (height $<8-10 \mathrm{~m})$, medium trees \\
& (height $>8-10 \mathrm{~m}$ and diameter $<20 \mathrm{~cm}$ ), mature trees (diameter $>20 \mathrm{~cm})$ \\
Species $(N=5)$ & Tree coverage $<20 \%$, pine, oak, pine and oak mixture, other species \\
Population $(N=3)$ & Population density $<25 \mathrm{hab} \mathrm{km}^{-2}, 25-100 \mathrm{hab} \mathrm{km}^{-2},>100 \mathrm{hab} \mathrm{km}^{-2}$ \\
Road density $(N=5)$ & $0-50 \mathrm{~km} \mathrm{~km}^{-2}, 50-100 \mathrm{~km} \mathrm{~km}^{-2}, 100-150 \mathrm{~km} \mathrm{~km}^{-2}, 150-200 \mathrm{~km} \mathrm{~km}^{-2},>200 \mathrm{~km} \mathrm{~km}^{-2}$ \\
\hline
\end{tabular}


the study area was classified, the proportion of burnt and non-burnt strata was calculated.

Then, the data were divided according to the burnt forest area. The division was performed for forest fires resulting in burnt area entailing 5-50 ha (small fires), 50-500 ha (medium fires) and larger than 500 ha (large fires). Exact 50 and 500 were considered medium and large fires, respectively. Fires burning less than 5 ha were initially considered, but eventually disregarded due to the resulting low predictive performance of the model. Before modelling the proportion of burnt area for the different size classes, a descriptive analysis of the size classes was performed, relating each size to the weather conditions (maximum temperature and relative humidity measured on the day of the fires), predominant fire type, number of events and also to the modelling variables. To test the differences between classes for some of these variables, ANOVAs were performed.

The model (Eq. 1) describes the linear relationship between the proportion of burnt area and the considered variables or predictors. To maintain the prediction within 0 and 1, the logit transformation of the burnt area ( $y$ ) was used as response variable. In total, four models were produced for each of the area burnt classes: small fires, medium fires, large fires and a general model considering all data available (including fires smaller than $5 \mathrm{ha}$ ).

$y_{i} \equiv \ln \left(\frac{p_{i}}{1-p_{i}}\right) \equiv X_{i}^{t} \beta+\varepsilon_{i}$

where $p_{i}$ is the observed proportion of burnt area. The average value of each strata for each of the variables considered was used to define $X$, being $\beta$ parameters to be estimated. Concerning the distribution of the error term, two model families were considered for the random errors of the models, binomial and quasibinomial. The final decision was made to better address potential over-dispersion in the response (i.e. additional unexplained variation) in those models having a residual deviance higher than the residual degrees of freedom. Both model families result in identical parameters, but the decision affects the estimation of the standard errors (with more conservative confidence intervals in the case of quasibinomial). After a preliminary analysis of the residual deviance, it was assumed a binomial distribution in the case of the small fires model and quasibinomial distribution in the rest of the models.

The strata had a variable size, with some covering large areas, whereas others were made of only a few cells. In order to take into account the relative importance of each of the stratum and its contribution to the model, weights were assigned according to the number of cells per stratum. The models were based on a weighted generalized linear model, and the parameters were fit with the maximum likelihood approach.
A measure of the goodness of fit of the models was calculated based on the pseudo- $R^{2}$ of the predicted versus the observed values of burnt area (Eq. 2), with the same weights as in the models, following:

$$
R^{2}=1-\frac{\sum w_{i}\left(y_{i}-\hat{y}_{i}\right)^{2}}{\sum w_{i}\left(y_{i}-\sum \frac{w_{i} y_{i}}{\sum w_{i}}\right)^{2}}
$$

where $w_{i}$ is the weight for stratum $i$, representing the area in raster cells, and $\hat{y}_{i}$ is the predicted percentage of area burnt.

In all the models, the logarithmic transformation of the road density and slope was applied in order to transform the distribution of the data. Finally, the predictions of the models were observed for different values of the variables selected.

\section{Results}

In the period studied, a total number of 10,722 fire events occurred in the study area, burning 301,483.5 ha of land, of which $285,024.2$ ha were forest land (Fig. 1); thus, $21.9 \%$ of forest land was burnt during the studied period. The coexistence of different land uses in the region is remarkable (Fig. 1, left); it can be observed that many fires occurred in locations where there was interaction between different land uses and fuel compositions. As in other Mediterranean countries, the number of human-caused fires in the region was larger than the number of natural fires: deliberate fires $(N=3308)$ and fires due to negligence and accidents $(N=4475)$ were the most common ones, fires due to accidents and human negligence were responsible for the largest burnt forest area (54\% of the forest burnt area), and natural fires, caused by lightning, represented about $24 \%$ of the total burnt forest area.

There were differences in the spatial distribution of fires (Fig. 2). Whereas there were a high number of small fires regularly distributed across the study area, when considering large fires, there were few and irregularly distributed, prevailing in interior forest areas rather than coastal. Hence, there were qualitative differences in the distribution of fire events by size class, in both number and spatial distribution. In this way, small fires represented only $2.7 \%$ of the total burnt forest area, medium fires represented $8.1 \%$, and large fires represented $87 \%$, despite the fact that the respective number of fires by those classes was 585,146 and 59 fires. Fire recurrence was observed in some locations (Fig. 2, right), where there was overlapping between fires of different sizes occurring in different years during the studied period.

Concerning the forest burnt area (Fig. 3), 1994 and 2012 were the years when more forest land was burnt. A few fires were responsible for large burnt areas, whereas there were 

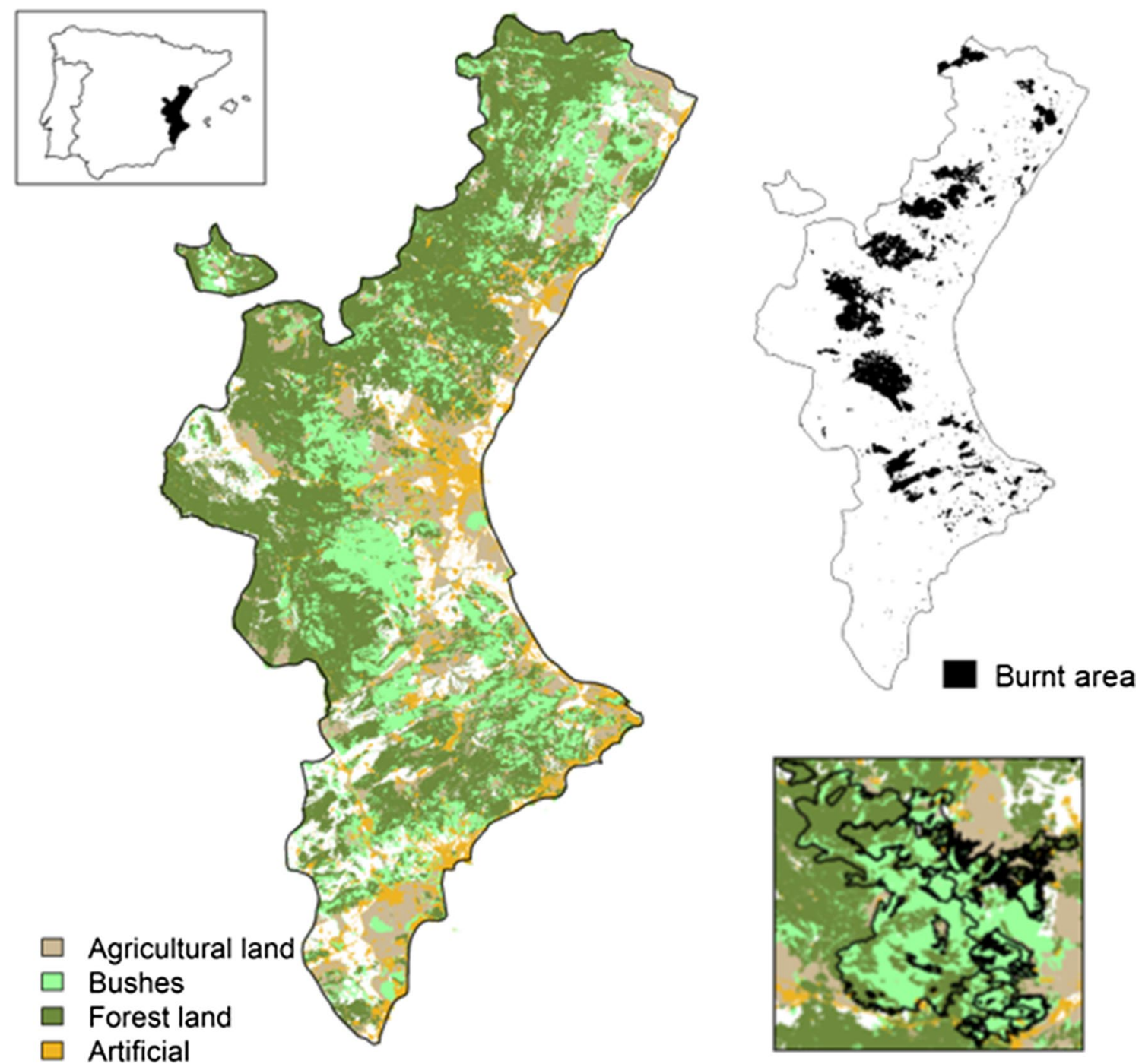

Fig. 1 Main land uses (left) and location of reported burnt area (right, up) in the region (Comunitat Valenciana, Eastern Spain) during the period 1993-2015. Both maps are overlapped in the illustration (right, bottom)

frequent fire events resulting in small areas burnt. Grouped by size classes, 7968 ha of forest land was burnt by 585 small fires, 23,247 ha by 146 medium fires and 248,653 ha by 59 large fires. An extreme example was in 2012, when only two forest fires were responsible for 48,000 ha of forest land burnt.

Fires occurred mainly in pine forest ( $P$. halepensis) and when the most common fuel corresponded to areas covered with bushes and small trees. In average, each fire burnt 26.58 ha of forest land (Standard error $(\mathrm{SE})=5.46$ ). For large fires, surface and crown fire played an important role, whereas small fires spread mainly through surface, based on area burnt (Table 2, based on Valenciana 2018). The mean maximum temperature and relative humidity measured on the day of the fires for all fires together (including fires smaller than $5 \mathrm{ha}$ ) were $15.5^{\circ} \mathrm{C}$
$(\mathrm{SE}=0.09)$ and $44.15 \%$, respectively $(\mathrm{SE}=0.26)$. When analysed separately (Table 2), there were differences in the climatic variables for the small, medium and large fires. Fire size increases as the mean maximum temperature increases, whereas the relative humidity decreases. Results for altitude showed that large fires occurred at higher altitudes and in barely populated areas. The statistical comparison of the three size classes, performed through oneway ANOVA tests and Tukey test for multiple pairwise comparisons, showed significant differences among the size classes ( $p$ value $<0.001$ ) for burnt forest surface and maximum temperature, but not for relative humidity ( $p$ value $=0.107$ ). The largest differences occurred between the small and large size classes.

The coefficients of the models (Table 3) were significant and did not show strong correlations between the variables, 
(a) 5-50 ha

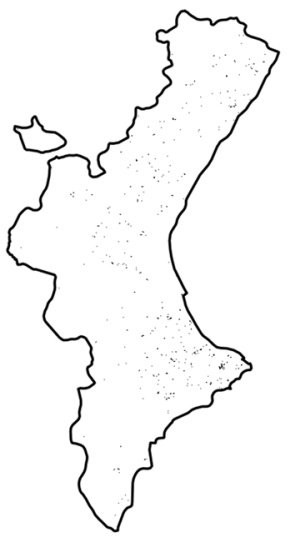

(b) 50-500 ha

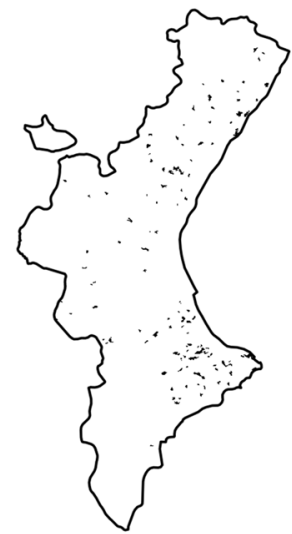

(c) $>500$ ha

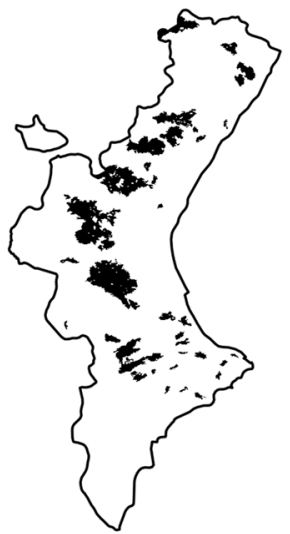

$\square>500$ ha

$\square$ 50-500 ha

$\square \quad 5-50$ ha

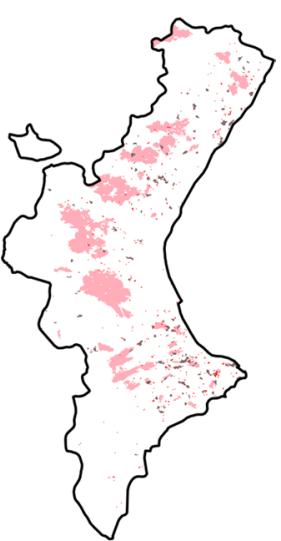

- burnt area

Fig. 2 Distribution of burnt areas along the period 1993-2015 in the Comunitat Valenciana (Eastern Spain) according to extent of fire, i.e. a small, $\mathbf{b}$ medium and $\mathbf{c}$ large fires. Small, medium and large fires overlapped (right)
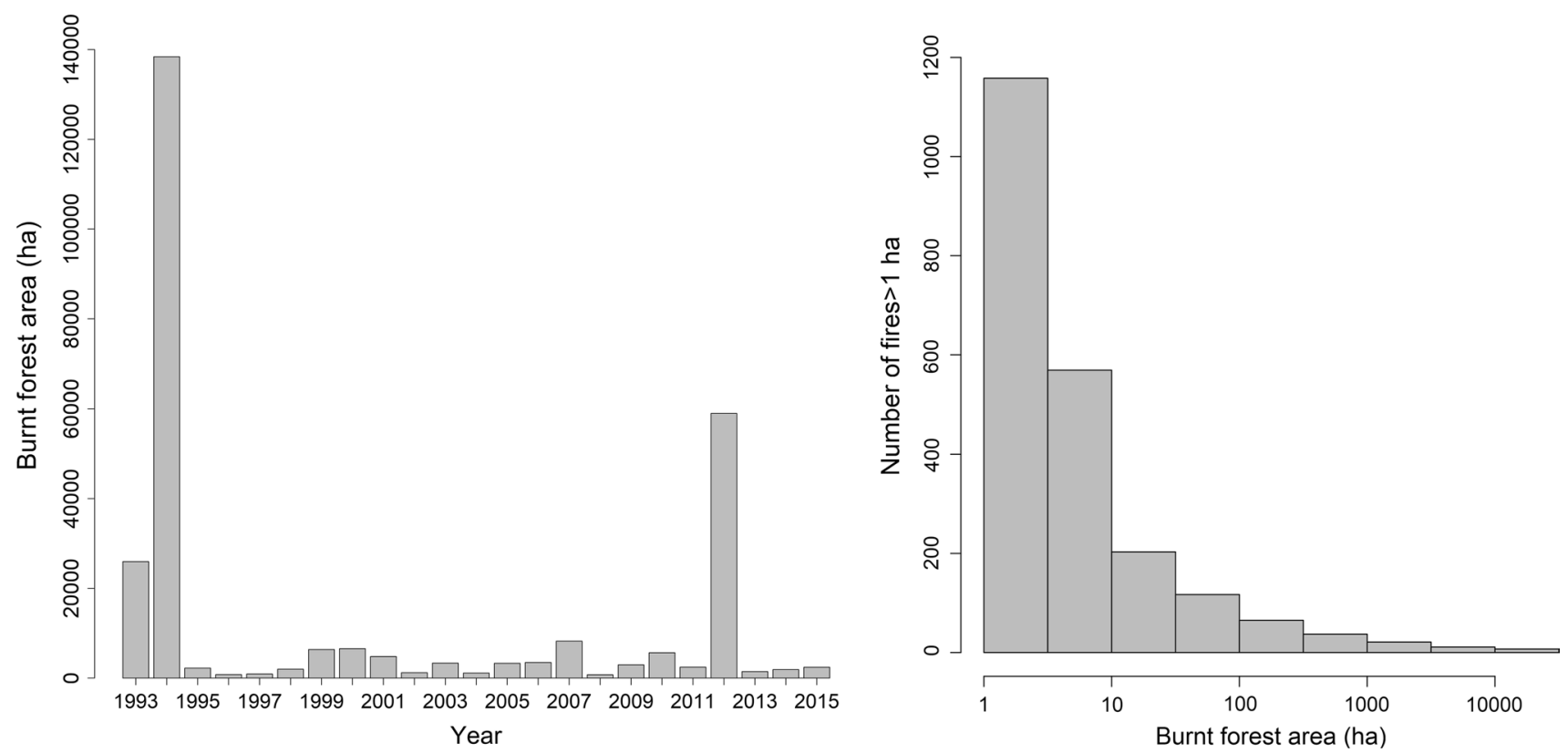

Fig. 3 Annual total burnt forest area in the Comunitat Valenciana, and number of fires in relation to the burnt forest area during the period 1993-2015

indicating multicollinearity. During the fitting process, nonsignificant variables or factor levels were removed.

The broad classification of species composition resulted to be less significant than expected for some classes. The proportion of burnt area increased as a response to the presence of pine (in the large fires model and all fires model) and, at a lower level, pine and oak mixture $\left(\beta_{2}\right)$. Small fires did not seem to be dependent on the present species, happening regardless differences in species composition. Pasture lands $\left(\beta_{3}\right)$ presented a higher probability of small fire occurrence. The presence of bushes with small trees $\left(\beta_{4}\right)$ was positively related to all fire sizes.

On the other hand, the presence of medium $\left(\beta_{5}\right)$ and mature trees $\left(\beta_{6}\right)$ seemed to reduce the probability of fire occurrence. The squared road density $\left(\beta_{8}\right)$ relates negatively with proportion of burnt area in all the cases. Hence, the 
Table 2 Principal variables of fire events classified by size in Eastern Spain (Comunitat Valenciana) during the period 1993-2015

\begin{tabular}{llll}
\hline Fire size (ha) & $5-50$ & $50-500$ & $>500$ \\
\hline$N$ & 585 & 146 & 59 \\
& $5.45 \%^{\mathrm{a}}$ & $1.36 \%^{\mathrm{a}}$ & $0.55 \%^{\mathrm{a}}$ \\
Burnt forest surface (ha) & 7968.08 & $23,247.46$ & $248,653.9$ \\
& $2.7 \%^{\mathrm{b}}$ & $8.1 \%^{\mathrm{b}}$ & $87.2 \%^{\mathrm{b}}$ \\
Mean burnt surface (ha) & $13.62(0.42)$ & $159.22(8.64)$ & $4214.47(835.09)$ \\
Forest formation & $P$. halepensis $^{\mathrm{b}}$ & P. halepensis & P. halepensis \\
& $22.26 \%^{\mathrm{b}}$ & $21.53 \%^{\mathrm{b}}$ & $24.25 \%^{\mathrm{b}}$ \\
Fuel type & Low vegetation cover & Bushes/small trees & Bushes/small trees \\
& $44.9 \%^{\mathrm{c}}$ & $41.01 \%^{\mathrm{c}}$ & $48.74 \%^{\mathrm{c}}$ \\
Fire type & Surface & Surface & Surface, surface and crowns \\
Mean relative humidity $(\%)$ & $41.17(1.05)$ & $40.12(1.95)$ & $33.98(2.92)$ \\
Mean max temperature $\left({ }^{\circ} \mathrm{C}\right)$ & $15.21(0.40)$ & $16.53(0.86)$ & $21.03(1.49)$ \\
Altitude (m) & $414.67(12.31)$ & $471.14(22.21)$ & $617(32.25)$ \\
Slope (\%) & $16.93(0.51)$ & $20.38(1.2)$ & $16.84(1.38)$ \\
Population density (hab km $\left.{ }^{-2}\right)$ & $37.44(13.21)$ & $20.75(11.03)$ & $9.2(5.55)$ \\
\hline
\end{tabular}

The standard error is represented in parenthesis

${ }^{a}$ Percentage of total number of fires, ${ }^{b}$ percentage of total burnt forest area, ${ }^{c}$ percentage of the dominant fuel type coverage present in each fire size class. In the case of altitude, slope and population density, the values were calculated including all the burnt area associated with the fire event higher road density, the lower the proportion of burnt area. The regression coefficients were lower in the large fires model, so there are fewer large fires when the road network is denser. The variable slope without transformation $\left(\beta_{9}\right)$ is positively related to fire occurrence for all the sizes. The square transformation of the slope $\left(\beta_{10}\right)$ gives negative values for the general and the large fires models, being nonsignificant for the rest of the models. In this way, where there are steeper slopes, there is less area burnt by large fires. According to all models, altitude $\left(\beta_{11}\right)$ is negatively related to proportion of burnt area; the higher the altitude, less proportion of burnt area. The only significant aspect class was east $\left(\beta_{12}\right)$, except for the small fires, which did not show dependence on aspect to occur. Population density $\left(\beta_{13}\right)$ was significant for all the models and negatively related to proportion of burnt area in all the size models. Modelling results show that where there is more population, the proportion of burnt forest reduces.

Regardless the large number of events classified as small fires, the consideration of the proportion of burnt area for each one of them is limited by the use of a grid with the average values of part of the modelling variables (slope, altitude, road and population density). For the large fires, the amount of grid points (average values per cell) that would fall within the fire event is higher, allowing more values for the construction of the models; on the contrary, several small events count only one value (i.e. there is one value per cell). As a result, predictions for slope must be limited to values lower than 60\%; after this threshold, small and medium events are poorly represented in the data available, and the lines are a mere projection of the trend following the exponential transformation used in the model (Fig. 4). For the altitude variable, all models behave as expected and show a decrease in the proportion of burnt area as the altitude increased. In this case, the predictions of burnt area for all fires and large fires almost overlapped completely.

In general terms, the proportion of burnt forest land by large fires is lower when the road density increases, whereas the area burnt by small and medium fires is larger when the road density is between 100 and $200 \mathrm{~km} \mathrm{~km}^{-2}$ (Fig. 4). Similarly, the burnt area is lower as the population density increases, for all fire sizes, reflecting the fact that human presence is perhaps a driver for more frequent ignitions and small fires but do not necessarily translates in larger burnt areas, as highly populated areas do not host large forests and the area of the fire events is smaller.

Results for the pseudo- $R^{2}$ of the observed values versus the predicted values are: 0.14 (small fires), 0.22 (medium fires), 0.55 (large fires) and 0.57 (general model for all fires). The preliminary model for very small fires $(<5$ ha) resulted in a pseudo- $R^{2}=0.02$, and no further analysis was performed. The small fires model is limited by the discrete nature of the area covered by these events, restricting the data to unique values for each cell or fire event. The dispersion in this case was higher than for the rest of the models. 
Table 3 Principal variables of fire events classified by size in the Comunitat Valenciana during the period 1993-2015

\begin{tabular}{|c|c|c|c|c|}
\hline Variable & $\begin{array}{l}\text { Small } \\
(5-50 \text { ha })\end{array}$ & $\begin{array}{l}\text { Medium } \\
\text { (50-500 ha) }\end{array}$ & $\begin{array}{l}\text { Large } \\
(>500 \text { ha })\end{array}$ & All fires \\
\hline$\beta_{0}$ & -5.809 & -4.509 & -0.715 & -0.707 \\
\hline$\beta_{1}$ (pine) & & -0.322 & 0.6 & 0.424 \\
\hline$\beta_{2}$ (mixture) & & & 0.479 & \\
\hline$\beta_{3}$ (pasture) & 2.062 & & & \\
\hline$\beta_{4}$ (bushes and small trees) & 0.39 & 0.676 & 0.371 & 0.445 \\
\hline$\beta_{5}($ medium trees $)$ & -0.567 & & -1.441 & -1.19 \\
\hline$\beta_{6}$ (mature trees) & -0.355 & & -1.936 & -1.583 \\
\hline$\beta_{7}$ (roads) & 0.026 & 0.028 & 0.007 & 0.006 \\
\hline$\beta_{8}\left(\operatorname{roads}^{2}\right)$ & $-6.5 \times 10^{-3}$ & $-8.3 \times 10^{-5}$ & $-5.428 \times 10^{-5}$ & $-4.235 \times 10^{-5}$ \\
\hline$\beta_{9}$ (slope) & 0.035 & 0.045 & 0.105 & 0.101 \\
\hline$\beta_{10}\left(\right.$ slope $\left.^{2}\right)$ & & & $-1.83 \times 10^{-3}$ & $-1.66 \times 10^{-3}$ \\
\hline$\beta_{11}$ (altitude) & $-1.33 \times 10^{-3}$ & $-1.69 \times 10^{-3}$ & $-0.97 \times 10^{-3}$ & $-1.04 \times 10^{-3}$ \\
\hline$\beta_{12}$ (East) & & $0.200 * *$ & $0.067 *$ & $0.076^{*}$ \\
\hline$\beta_{13}$ (population) & -0.506 & -0.608 & -0.615 & -0.576 \\
\hline Variable & $\mathrm{SE}$ & SE & SE & SE \\
\hline$\beta_{0}$ & 0.136 & 0.220 & 0.108 & 0.106 \\
\hline$\beta_{1}$ (pine) & & 0.083 & 0.047 & 0.045 \\
\hline$\beta_{2}$ (mixture) & & & 0.083 & \\
\hline$\beta_{3}$ (pasture) & 0.294 & & & \\
\hline$\beta_{4}$ (bushes and small trees) & 0.049 & 0.070 & 0.037 & 0.037 \\
\hline$\beta_{5}($ medium trees $)$ & 0.089 & & 0.064 & 0.062 \\
\hline$\beta_{6}$ (mature trees) & 0.062 & & 0.062 & 0.059 \\
\hline$\beta_{7}$ (roads) & $1.36 \times 10^{-3}$ & $2.25 \times 10^{-3}$ & $1.107 \times 10^{-3}$ & $1.02 \times 10^{-3}$ \\
\hline$\beta_{8}\left(\operatorname{roads}^{2}\right)$ & $4.12 \times 10^{-6}$ & $7.257 \times 10^{-6}$ & $3.979 \times 10^{-6}$ & $3.569 \times 10^{-6}$ \\
\hline$\beta_{9}$ (slope) & 0.006 & 0.002 & 0.004 & 0.004 \\
\hline$\beta_{10}\left(\right.$ slope $\left.^{2}\right)$ & & & $1.015 \times 10^{-4}$ & $1.002 \times 10^{-4}$ \\
\hline$\beta_{11}$ (altitude) & $1.02 \times 10^{-4}$ & $1.570 \times 10^{-4}$ & $6.788 \times 10^{-5}$ & $6.906 \times 10^{-5}$ \\
\hline$\beta_{12}$ (East) & & 0.067 & 0.03 & 0.003 \\
\hline$\beta_{13}$ (population) & 0.020 & 0.041 & 0.021 & 0.019 \\
\hline
\end{tabular}

$S E$ standard error

All variables were significant: $p$ value $<0.001$. $* * p$ value $0.01,{ }^{*} p$ value 0.05

\section{Discussion}

The present study focused on a characterization analysis of the forest fires in Eastern Spain (Comunitat Valenciana), identifying the possible variables related to the size of the areas eventually burnt. The extensive data from different sources compiled in this study were the basis of a comprehensive analysis from different approaches, considering topography and socio-economic variables. These data also provided the opportunity to study and model forest fires at different scales, as it included information at stand level and at landscape level.

Combining all the different data sets also produced limitations, which were solved by using raster versions of the maps. The use of data in raster facilitated the computation processes related to the identification of areas of similar characteristics. However, this was at the expense of reducing spatial information, as the vector information is transformed into raster. Despite this, the reduction in information was minimal compared to the advantages in data processing and did not affect the results significantly.

Another limitation was related to the variables extracted from the MFE50 (1997-2006) map and its combination with the fire data set (1993-2015), as unfortunately did not have a full overlapping in their timeframes (the MFE50 measurements in the study area were done between 2000 and 2003). Although this would not have an overall effect, as most of the land uses have not been significantly changed, it could, however, produce bias in those locations with a fire event previous or subsequent to the MFE50 measurements. 

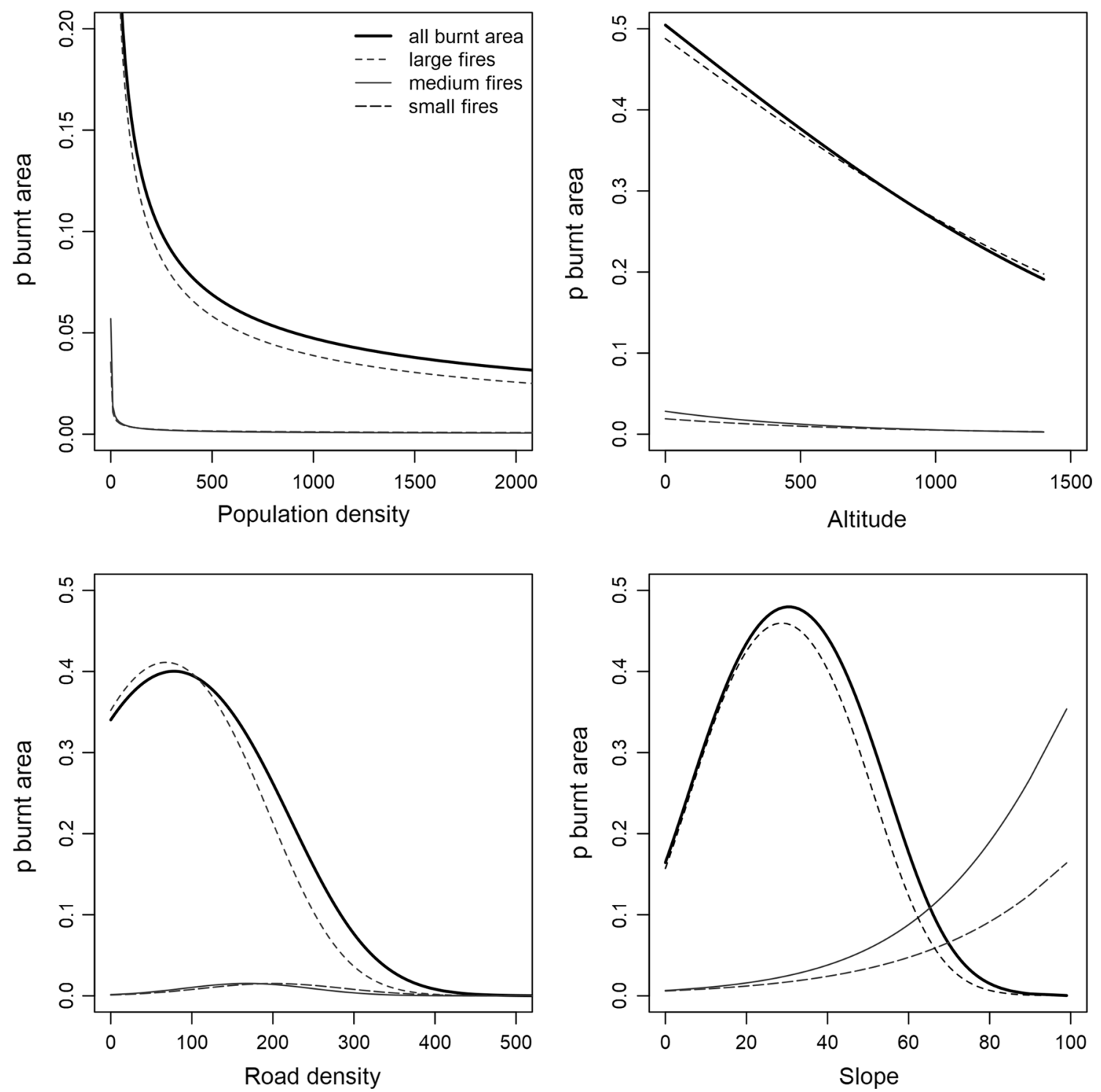

Fig. 4 Marginal dependence of the proportion of burnt area by forest fires for a pine forest on east aspect and bushes and small trees, as a function of altitude ( $\mathrm{m}$ above sea level), slope (\%), population density

(hab $\mathrm{km}^{-2}$ ) and road density $\left(\mathrm{km} \mathrm{km}^{-2}\right.$ ), according to the models for small (5-50 ha), medium (50-500 ha) and large fires (> 500 ha)

In those cases, the forest structure, species composition and fuel characteristics between fires, among others, could have changed (see Cardil et al. 2017), resulting in an over-representation of land uses related to bushes and small trees in previously burnt mature forests. This limitation is difficult to overcome as there are no prior maps with an adequate description of the species composition and structure, and this limitation has also been present in previous studies with a similar objective (e.g. González and Pukkala 2007; Marques et al. 2011a). The preliminary analysis of the data assessing this issue and the model performance resulting suggested that any potential bias due to the timeframe sequence of the data was limited and did not affect the overall analysis.

Concerning the variables chosen, this study improved the models created for neighbouring regions in the Mediterranean area (González and Pukkala 2007) by explicitly including socio-economic factors. The division concerning area burnt also improved the approach taken by Marques et al. (2011a), as permits analysing the fire size distribution and the relation of the variables with the size of the burnt areas. Although several studies addressed fire risk of large fires and mega-fires (e.g. Attiwill and Adams 2013; de la Barrera et al. 2018; Williams 2013), the use of different fire size ranges in Mediterranean areas for analysis and modelling is still an approach seldom proposed. In this line, a similar study in Portugal (Moreira et al. 2010) utilized size classes to explore 
the ignition patterns in relation to final burnt area, showing that most of the area was burnt by a few large fires, which tended to be associated with remote areas, with low human presence, far away from roads, and dominated by shrubs and forests. In agreement with our results, Moreira et al. (2010) remarked the influence of human presence as a driver of ignitions but also being, at the same time, negatively related to large fires, most probably due to more effective suppression efforts and higher detection opportunities, or by the fuel discontinuities that the road network generates (Narayanaraj and Wimberly 2012). Ganteaume and Jappiot (2013) also studied the explanatory factors behind the occurrence of large fires, which represented $78 \%$ of the total burnt area in Southern France and were positively related to the presence of shrubs and pasture as well as to low road densities.

The exploratory analysis of the fire data in the area led to a spatial and temporal characterization, showing emergent patterns when combined with land use data, climatic and topographical variables. At spatial level, the models considered slope, altitude and aspect, which acted as proxy variables to explain other more complex interactions. For instance, altitude explained the gradient related to the species composition as well as changes in human occupation, although did not necessarily explain the climatic gradient as in González et al. (2006) as in the region the altitude ranges are narrower and does not have the same effect. Regarding the temporal characterization, between-year variations showed no clear pattern, except for some events related to drought conditions. The analysis of the weather conditions was necessarily exploratory, as a specific analysis on the effect of weather conditions affecting the potential fire spread, even when it has been proved to be a determinant factor (Duane and Brotons 2018; Haines 1989; Van Wagner 1987), was not intended.

The models revealed the relations of the variables explored, being the fuel type and the presence of some species the most relevant fire-prone variables. Mediterranean forests are characterized by their structural and compositional heterogeneity, being common the abundance of bushes, either as bushlands or as part of the lower forest strata. The results showed that bushes and small trees are the fuel class that mainly affects the proportion of burnt area. In this sense, Marques et al. (2011a) also found that shrubs were the land cover type most related to fire occurrence, which is in agreement with González and Pukkala (2007), Ganteaume and Jappiot (2013) and Moreira et al. (2010). On the other hand, pasture lands were only positively related to the small forest fires (as pasture lands present low amounts of inflammable material that ignite and burn rapidly). On forested areas, tree size appeared to have an influence on the spread of fires, being mature forest the least prone to result on large fires. These results agreed with the idea that mature even-aged forest can generate gaps in the vertical ladder of fuels, therefore being less susceptible to initiate active crown fires (González et al. 2006). However, it can be also considered that even if these forests are more resistant to the effects of fire (González et al. 2007), any virulent stand-replacing fire occurring after 2003 (MFE50 measurements) should have changed the structure and composition of the forest (Puerta-Piñero et al. 2012), generating some bias on the results.

Besides fuel types, the species composition influenced the size of the fire events. The most abundant species is pine, which was related to the occurrence of large fires. According to Alvarez et al. (2012), in poorly managed and undisturbed stands, $P$. halepensis present closer canopies (forming a denser forest structure), increasing the risk of crown fires. Moreover, due to the storage of seeds in its canopy, $P$. halepensis regenerates abundantly after a fire (Pausas et al. 2004). Other species (e.g. beech, ash, etc.) and oak did not show a significant relation with the fires, which can be explained by the fact that there are very few forest lands where these species dominate. At the same time, mixtures of oaks and pines were positively related to large fires, which links with the high recovering capacity of the mixed Pinus-Quercus Mediterranean-type after large and intense fires (Puerta-Piñero et al. 2012), although is not a common compositional type in the region.

Concerning topographical variables, the results were largely consistent with González and Pukkala (2007). Slopes between 12 and 35\% presented the higher proportion of burnt area according to the general and the large fires models. Usually, higher altitudes present steeper slopes, larger forest coverage and less accessibility. There is a point (slope $>60 \%$ ) where this trend changed, being the small and medium fires more common, which could be the result of the extrapolation derived from applying exponential transformations or due to the fact that a small fire would cover a lower range of variations in slope than a large one. It can also be explained by the reduction in tree coverage, in such a way that fires do not reach larger sizes due to the lack of fuel and the climatic conditions (increase in relative humidity and temperature decrease). In this sense, the results of all models concerning altitude are consistent, showing that the higher the altitude, the lower the proportion of burnt area (similar trend than in González and Pukkala 2007; Guo et al. 2017; Pourtaghi et al. 2016). This relationship is stronger in the general model and for the large fires model, whereas the response to altitude of medium and small fires is less steep. As a result, forest fires at lower altitudes seem to burn larger areas than in higher locations.

Concerning road density, areas with a dense road network presented more ignitions, as in Wittenberg and Malkinson (2009) and Gonzalez-Olabarria et al. (2011), reflecting that when the accessibility increases, human-caused ignitions are more likely to occur (see Martínez et al. 2009). On the other 
hand, when the road network is limited, there were few fire events but resulted in large areas burnt. This can be directly related to the accessibility and the fire detection opportunities, which are lower in areas with less transit. In the region, although the main road axis in the area is parallel to the sea, connecting the most populated areas of the Mediterranean corridor, the road network is denser in the central areas, connecting the capitals of the region with the nearest towns and villages. The interface between the dense road network areas and the mountains entails the areas with the larger fires. The areas closer to the sea have low forest areas and therefore have less burnt area. It also could be explained by: (1) the higher efforts in populated areas for monitoring and the probabilities of noticing the fires before it gets large, as the opportunities for quick detection and early attack increase, (2) accessibility due to the road network, facilitating an efficient movement of suppression efforts, and (3) uneven distribution of forest lands and roads acting as fire breaks, if the fire has not gain enough momentum. Regarding population density, at lower population densities the proportion of burnt forest land is large, showing a similar behaviour than the road density variable. Consistent with Marques et al. (2011a), in areas densely populated, the fire events are more numerous. Although in urban areas with high population density, the burnt surface decreases.

The results emphasise the differences in the relations of the spatial factors explaining the burnt area, according to the fire size, with consequences upon potential prevention policies. For instance, although small fires are frequent in number, they present a limited impact. Many of the small fires are human-caused, either by negligence, accidents or deliberate. González-Olabarria et al. (2015) showed that the occurrence factors and spatial aggregation patterns of ignitions presented differences according to their causes (with special emphasis on human-caused fires), highlighting the role of educational and law-enforcement measures in reducing the number of human-caused fires in the region (Gonzalez-Olabarria et al. 2012).

Medium and large fires, on the other hand, are the result of additional limitations, particularly affecting the accessibility and the presence of some specific fuel types. In these cases, a way to prepare preventive measures should include fire detection and suppression resources at specific locations during the fire season. In addition, improving and maintaining the road network on strategic places can help to efficiently fight incipient fires in hazardous areas. Finally, planning the allocation of fuel treatments in order to reduce fire spread (Finney et al. 2008) and support suppression efforts (Gonzalez-Olabarria et al. 2019) could serve both for prevention and as a mitigation strategy to be considered. The reduction and fragmentation of the fuel loads through forest management can lead to less flammable structures (Baeza et al. 2005), reducing the spread of fires and extreme fire behaviour favoured by fuel accumulation (Finney and Cohen 2003).

Raising the level of ambition, a long-term strategy should consider swifts of species, breaking the compositional continuity on large areas covered with the highly flammable $P$. halepensis, a tree species that favours and takes advantage on the occurrence of high-intensity stand-replacing fires (Bond and Midgley 1995). For this purpose, allocating stands of broadleaved trees (deciduous and evergreen) and short-needled conifer forest types has shown a remarkable impact in taming fire behaviour when a fire arrives from adjacent more flammable pine forest (Fernandes et al. 2010). Finally, bush biomass control has revealed to be always a positive fire prevention strategy, especially when focussed on cleaning the transition zones between agricultural and forest land use, as some authors reported these areas to be prone to ignition (Gonzalez-Olabarria et al. 2011; Martínez et al. 2009), although taking into consideration the risk of erosion associated with vegetation modifications in arid Mediterranean areas (Selkimäki et al. 2012). These areas could be considered as firebreaks, committing more resources for its maintenance and tightened up regulations for the use of fire. At this level, stable fire management policies are key to mitigate wildfires (Mateus and Fernandes 2014).

\section{Conclusions}

In general, the variables have more explanatory power in large fires than in the small and medium fires. When burnt area is modelled irrespective of the fire size, the model mainly is explaining large fire events. The use of different models to explain fire events according to their size is necessary in future efforts, as the relationship of the variables and the burnt areas is size dependent.

The resulting models can be applied to analyse the effect of each fire size class in Mediterranean conditions by describing the most influencing variables and could help elaborate fire prevention strategies and even complement land-planning schemes. The results should be complemented with studies considering the influence of fire danger indexes on potential fire spread, to include additional short-term prevention measures.

Acknowledgements Open access funding provided by University of Eastern Finland (UEF) including Kuopio University Hospital. We would like to thank Prof. Timo Pukkala for his kind advice in the finalization of this manuscript. We also want to thank to Conselleria de Agricultura, Medio Ambiente, Cambio Climático y Desarrollo Rural for providing the necessary data to complete this study, and the School of Forest Sciences (University of Eastern Finland). We would like to thank the Finnish Cultural Foundation (Grant No. 55191504) (North Karelia Regional Fund) for their support. We are grateful to the European Union's H2020 research and innovation programme under the Marie Sklodowska-Curie Grant Agreement No. 691149 (SuFoRun) 
for their kind financial help. Dr. José Ramón González Olabarria also acknowledges funding from Spanish Ministry of Economy and Business (MINECO) (Ref. RYC-2011-08983) and from Agency for the Research Centre of Catalonia (CERCA Programme/Generalitat de Catalunya). Finally, we thank the editor and two anonymous reviewers for their constructive comments on the earlier version of this manuscript.

\section{Compliance with ethical standards}

Conflict of interest The authors declare that they have no conflict of interest.

Open Access This article is licensed under a Creative Commons Attribution 4.0 International License, which permits use, sharing, adaptation, distribution and reproduction in any medium or format, as long as you give appropriate credit to the original author(s) and the source, provide a link to the Creative Commons licence, and indicate if changes were made. The images or other third party material in this article are included in the article's Creative Commons licence, unless indicated otherwise in a credit line to the material. If material is not included in the article's Creative Commons licence and your intended use is not permitted by statutory regulation or exceeds the permitted use, you will need to obtain permission directly from the copyright holder. To view a copy of this licence, visit http://creativecommons.org/licenses/by/4.0/.

\section{References}

Agee JK, Skinner CN (2005) Basic principles of forest fuel reduction treatments. For Ecol Manage 211(1-2):83-96

Ager AA, Preisler HK, Arca B, Spano D, Salis M (2014) Wildfire risk estimation in the Mediterranean area. Environmetrics 25(6):384-396

Alcasena FJ, Salis M, Vega-García C (2016) A fire modeling approach to assess wildfire exposure of valued resources in central Navarra, Spain. European Journal of Forest Research 135(1):87-107

Alexandrian D, Esnault F (1999) Public policies affecting forest fires in the Mediterranean Basin. FAO Forestry Paper, pp 39-58

Alvarez A, Gracia M, Vayreda J, Retana J (2012) Patterns of fuel types and crown fire potential in Pinus halepensis forests in the Western Mediterranean Basin. For Ecol Manage 270:282-290

Attiwill PM, Adams MA (2013) Mega-fires, inquiries and politics in the eucalypt forests of Victoria, south-eastern Australia. For Ecol Manage 294:45-53

Badia A, Saurí D, Cerdan R, Llurdés JC (2002) Causality and management of forest fires in Mediterranean environments: an example from Catalonia. Glob Environ Change Part B Environ Hazard $4(1): 23-32$

Baeza MJ, Valdecantos A, Vallejo VR (2005) Management of Mediterranean shrublands for forest fire prevention. New research on forest ecosystems. Nova Science Publishers Inc., New York, pp $37-60$

Barberà MJ, Niclòs R, Estrela MJ, Valiente JA (2015) Climatology of the stability and humidity terms in the Haines Index to improve the estimate of forest fire risk in the Western Mediterranean Basin (Valencia region, Spain). Int J Climatol 35(7):1212-1223

Bettinger P, Boston K, Siry JP, Grebner DL (2016) Forest management and planning. Academic Press, New York

Bond WJ, Midgley JJ (1995) Kill thy neighbour: an individualistic argument for the evolution of flammability. Oikos 73:79-85

Botequim B, Arias-Rodil M, Garcia-Gonzalo J, Silva A, Marques S, Borges JG, Oliveira MM, Tomé M (2017) Modeling post-fire mortality in pure and mixed forest stands in Portugal—A forest planning-oriented model. Sustainability 9(3):390

Cardil A, Mola-Yudego B, Blázquez-Casado A, González-Olabarria JR (2017) Fire and burn severity assessment: calibration of Relative Differenced Normalized Burn Ratio (RdNBR) with field data. J Environ Manage 235:342-349

Chuvieco E, Martin M (2004) Nuevas tecnologias para la estimación del riesgo de incendios forestales. Ministerio de Educación y Ciencia, Madrid, España

Cui W, Perera AH (2008) What do we know about forest fire size distribution, and why is this knowledge useful for forest management? Int J Wildland Fire 17(2):234-244

de la Barrera F, Barraza F, Favier P, Ruiz V, Quense J (2018) Megafires in Chile 2017: monitoring multiscale environmental impacts of burned ecosystems. Sci Total Environ 637:1526-1536

Duane A, Brotons L (2018) Synoptic weather conditions and changing fire regimes in a Mediterranean environment. Agric For Meteorol 253:190-202

European Commission JRC (2011) Forest fires in Europe 2010. Official Publication of the European Communities, EUR 24910.

Fernandes PM, Luz A, Loureiro C (2010) Changes in wildfire severity from maritime pine woodland to contiguous forest types in the mountains of northwestern Portugal. For Ecol Manage 260(5):883-892

Finney MA (2001) Design of regular landscape fuel treatment patterns for modifying fire growth and behavior. For Sci 47(2):219-228

Finney MA, Cohen JD (2003) Expectation and evaluation of fuel management objectives. In: USDA forest service proceedings RMRSP-29, pp. 353-366

Finney MA, Seli RC, McHugh CW, Ager AA, Bahro B, Agee JK (2008) Simulation of long-term landscape-level fuel treatment effects on large wildfires. Int J Wildland Fire 16(6):712-727

Fox DM, Laaroussi Y, Malkinson LD, Maselli F, Andrieu J, Bottai L, Wittenberg L (2016) POSTFIRE: a model to map forest fire burn scar and estimate runoff and soil erosion risks. Remote Sens Appl Soc Environ 4:83-91

Gallego FJ (2010) A population density grid of the European Union. Popul Environ 31:460-473

Ganteaume A, Jappiot M (2013) What causes large fires in Southern France. For Ecol Manage 294:76-85

Goldammer JG (2003) Towards international cooperation in managing forest fire disasters in the Mediterranean region. Security and Environment in the Mediterranean. Springer, Berlin, pp 907-915

González JR, Pukkala T (2007) Characterization of forest fires in Catalonia (north-east Spain). Eur J For Res 126(3):421-429

González JR, Palahí M, Trasobares A, Pukkala T (2006) A fire probability model for forest stands in Catalonia (north-east Spain). Ann For Sci 63:169-176

González JR, Trasobares A, Palahi M, Pukkala T (2007) Predicting stand damage and tree survival in burned forests in Catalonia (North-East Spain). Ann For Sci 64(7):733-742

Gonzalez-Olabarria JR, Mola-Yudego B, Pukkala T, Palahi M (2011) Using multiscale spatial analysis to assess fire ignition density in Catalonia, Spain. Ann For Sci 68(4):861-871

Gonzalez-Olabarria JR, Brotons L, Gritten D, Tudela A, Teres JA (2012) Identifying location and causality of fire ignition hotspots in a Mediterranean region. Int J Wildland Fire 21(7):905-914

González-Olabarria JR, Mola-Yudego B, Coll L (2015) Different factors for different causes: analysis of the spatial aggregations of fire ignitions in Catalonia (Spain). Risk Anal 35(7):1197-1209

Gonzalez-Olabarria JR, Reynolds KM, Larrañaga A, Garcia-Gonzalo J, Busquets E, Pique M (2019) Strategic and tactical planning to improve suppression efforts against large forest fires in the Catalonia region of Spain. For Ecol Manag 432:612-622 
Guo F, Su Z, Wang G, Sun L, Tigabu M, Yang X, Hu H (2017) Understanding fire drivers and relative impacts in different Chinese forest ecosystems. Sci Total Environ 605:411-425

Haines DA (1989) A lower atmosphere severity index for wildlife fires. National Weather Digest 13:23-27

Hijmans RJ (2017) Raster: geographic data analysis and modeling. R package version 2.6-7. https://CRAN.R-project.org/package=raster

Instituto Nacional de Estadística (2018) Territorial statistics: CENSO1527148-Censo 2011: Total viviendas familiares. DPOP24523—Padrón: Población Total. https://www.ine.es/censo s2011_datos/cen11_datos_inicio.htm. Accessed 13 Feb 2019

Jiménez-Ruano A, Mimbrero MR, Jolly WM, de la Riva Fernández J (2019) The role of short-term weather conditions in temporal dynamics of fire regime features in mainland Spain. J Environ Manage 241:575-586

Loehle C (2004) Applying landscape principles to fire hazard reduction. For Ecol Manage 198(1-3):261-267

Marques S, Borges JG, Garcia-Gonzalo J, Moreira F, Carreiras JMB, Oliveira MM, Cantarinha A, Botequim B, Pereira JMC (2011a) Characterization of wildfires in Portugal. Eur J For Res 130(5):775-784

Marques S, Garcia-Gonzalo J, Borges JG, Botequim B, Oliveira MM, Tomé J, Tomé M (2011b) Developing post-fire Eucalyptus globulus stand damage and tree mortality models for enhanced forest planning in Portugal. Silva Fennica 45(1):69-83

Martínez J, Vega-Garcia C, Chuvieco E (2009) Human-caused wildfire risk rating for prevention planning in Spain. J Environ Manage 90(2):1241-1252

Mateus P, Fernandes PM (2014) Forest fires in Portugal: dynamics, causes and policies. Forest Context and Policies in Portugal. Springer, Cham, pp 97-115

Ministerio de Agricultura, Alimentación y Medio Ambiente (19972006) Mapa Forestal de España a escala 1:50.000. Ministerio de Agricultura, Alimentación y Medio Ambiente. Serie publicación digital. Madrid

Ministerio de Agricultura, Alimentación y Medio Ambiente (2012) Los incendios Forestales en España Decenio 2001-2010, Technical Report, Madrid

Ministerio de Agricultura, Pesca y Alimentación (2019) Los incendios Forestales en España Decenio 2006-2015. Área de Defensa contra Incendios Forestales, Technical Report, Madrid

Ministerio de Medio Ambiente (2006) Los incendios Forestales en España Decenio 1996-2005. Technical Report, Madrid

Moreira F, Catry FX, Rego F, Bacao F (2010) Size-dependent pattern of wildfire ignitions in Portugal: When do ignitions turn into big fires? Landsc Ecol 25(9):1405-1417

Moriondo M, Good P, Durao R, Bindi M, Giannakopoulos C, CorteReal J (2006) Potential impact of climate change on fire risk in the Mediterranean area. Clim Res 31(1):85-95

Narayanaraj G, Wimberly MC (2012) Influences of forest roads on the spatial patterns of human-and lightning-caused wildfire ignitions. Appl Geogr 32(2):878-888

Parente J, Pereira MG (2016) Structural fire risk: the case of Portugal. Sci Total Environ 573:883-893

Pausas JG, Fernández-Muñoz S (2012) Fire regime changes in the Western Mediterranean Basin: from fuel-limited to drought-driven fire regime. Clim Change 110(1-2):215-226
Pausas JG, Ribeiro E, Vallejo R (2004) Post-fire regeneration variability of Pinus halepensis in the eastern Iberian Peninsula. For Ecol Manage 203(1-3):251-259

Piñol J, Terradas J, Lloret F (1998) Climate warming, wildfire hazard, and wildfire occurrence in coastal eastern Spain. Clim Change 38(3):345-357

Pourtaghi ZS, Pourghasemi HR, Aretano R, Semeraro T (2016) Investigation of general indicators influencing on forest fire and its susceptibility modeling using different data mining techniques. Ecol Ind 64:72-84

Prăvălie R (2018) Major perturbations in the Earth's forest ecosystems. Possible implications for global warming. Earth Sci Rev 185:544-571

Puerta-Piñero C, Brotons L, Coll L, González-Olabarría JR (2012) Valuing acorn dispersal and resprouting capacity ecological functions to ensure Mediterranean forest resilience after fire. Eur J For Res 131(3):835-844

San-Miguel-Ayanz J, Moreno JM, Camia A (2013) Analysis of large fires in European Mediterranean landscapes: lessons learned and perspectives. For Ecol Manage 294:11-22

Selkimäki M, González-Olabarria JR, Pukkala T (2012) Site and stand characteristics related to surface erosion occurrence in forests of Catalonia (Spain). Eur J For Res 131(3):727-738

Turco M, Rosa-Cánovas JJ, Bedia J, Jerez S, Montávez JP, Llasat MC, Provenzale A (2018) Exacerbated fires in Mediterranean Europe due to anthropogenic warming projected with non-stationary climate-fire models. Nat Commun 9(1):3821

Valenciana G (2011) Plan de Acción Territorial Forestal de la Comunitat Valenciana. Conselleria de Infraestructuras, Territorio y Medio Ambiente

Valenciana G (2015) El territori forestal de la Comunitat Valenciana. CC BY 4.0 @. http://www.agroambient.gva.es/va/web/ medio-natural/el-territorio-forestal-de-la-comunitat-valenciana. Accessed 25 Feb 2019

Valenciana G (2018) Estadística completa de Incendios Forestales. CC BY 4.0 @ . http://www.agroambient.gva.es/es/web/prevencion-deincendios/estadistica-de-incendios-forestales. Accessed $25 \mathrm{Feb}$ 2019

Van Wagner CE (1987) Development and structure of the Canadian forest fire weather index system, vol 35. Canadian Forestry Service, Ottawa

Williams J (2013) Exploring the onset of high-impact mega-fires through a forest land management prism. For Ecol Manage 294:4-10

Wittenberg L, Malkinson D (2009) Spatio-temporal perspectives of forest fires regimes in a maturing Mediterranean mixed pine landscape. Eur J For Res 128(3):297

Publisher's Note Springer Nature remains neutral with regard to jurisdictional claims in published maps and institutional affiliations. 